\title{
Kesantunan Berbahasa: Studi pada Pembelajaran Daring
}

\author{
1Merri Silvia Basri, ${ }^{2}$ Hilma Safitri, ${ }^{3}$ M. Nur Hakim \\ ${ }_{1}^{1}$ Progam Studi Pendidikan Bahasa Jepang, Universitas Riau \\ 2Program Studi Sastra Inggris, Universitas Pamulang \\ 3Program Studi Informatika, Universitas Cokroaminoto Palopo \\ 1merrisilviabasri@gmail.com, 2hilmasaf@yahoo.com, ${ }^{3}$ nurhakim@uncp.ac.id
}

\begin{abstract}
Abstrak
Kesantunan berbahasa dalam proses pembelajaran merupakan hal yang penting untuk diterapkan dalam lingkungan belajar. Kesantunan tidak hanya dilakukan ketika proses pembelajaran dilaksanakan secara tatap muka, teapi juga dapat dilakukan secara daring. Hal ini agar peserta tutur bisa saling menerima dan memahami dari maksud yang disampaikan. Penelitian ini bertujuan untuk mengetahui kesantunan berbahasa mahasiswa selama melakukan pembelajaran daring. Penelitian ini menggunakan metode deskriptif kualitatif. Data dalam penelitian ini ialah tuturan mahasiswa dan dosen selama dilakukan pembelajaran daring, baik melalui aplikasi zoom, whatsapp, maupun google classroom. Sumber data dalam penelitian ini ialah mahasiswa Universitas Cokroaminoto Palopo. Hasil penelitian menunjukkan bahwa selama kegiatan pembelajaran daring mahasiswa dapat dikatakan santun dalam berbahasa. Terdapat 5 maksim yang termasuk pada tuturan pematuhan dan hanya maksim penghargaan dan kemufakatan yang terjadi pelanggaran dalam berbahasa.
\end{abstract}

Kata Kunci: Kesantunan berbahasa, tindak tutur, pembelajaran daring

\section{Pendahuluan}

Bahasa merupakan salah satu alat interaksi sosial yang digunakan oleh sekelompok masyarakat dalam proses berkomunikasi. Kegiatan berkomunikasi dapat dilakukan antara dua orang penutur maupun dalam skala besar. Berkomunikasi bertujuan untuk menjalin hubungan sosial antara satu penutur dengan penutur lainnya melalui pesan agar bisa saling dipahami. Komunikasi dapat dilakukan dengan menggunakan bahasa yang santun agar terdengar lebih baik dan bisa menjaga perasaan orang yang mendengar (Darwis, 2018).

Kegiatan berbahasa tidak terlepas dari aturan-aturan yang telah ditetapkan maupun disepakati oleh kelompok masyarakat. Aturan-aturan tersebut berkaitan dengan sikap santun yang digunakan oleh individu maupun sekelompok masyarakat untuk berkomunikasi secara lisan maupun tertulis. Sebagaimana pendapat yang dikemukakan Andriana (2014) bahwa penggunaan bahasa tidak hanya sebatas menyampaikan pesan agar bisa dipahami oleh lawan tutur, tetapi hal yang tidak kalah penting ialah membangun harmoni sosial. Hal tersebut tidak jauh berbeda dengan pendapat Alviah (2014) bahwa salah satu fungsi tindak tutur ialah dapat dikreasikan oleh penutur untuk menciptakan strategi-strategi dalam mewujudukan sikap kesantunan dalam berbahasa. Olehnya itu, penggunaan kata, frasa, struktur kalimat, maupun ekspresi jika diungkapkan secara lisan menjadi hal yang cukup penting dalam menciptakan komunikasi yang harmonis.

Kegiatan pembelajaran yang dilakukan sejak tahun tahun 2020 hingga saat ini ialah berorientasi pada pembelajaran daring karena situasi dan kondisi yang tidak bisa dilaksanakan secara tatap muka. Melihat kondisi tersebut, dengan perkembangan teknologi kegiatan pembelajaran daring dapat memanfaatkan penggunaan berbagai 
media maupun aplikasi sebagai penunjang proses pembelajaran agar tetap terlaksana. Aplikasi yang banyak digunakan hingga saat ini dalam pembelajaran ialah zoom, google classroom, whatsapp, dan berbagai aplikasi lainnya yang dianggap mudah untuk digunakan. Hadirnya aplikasi-aplikasi tersebut tentunya sangat memudahkan proses pembelajaran untuk terus dilaksanakan. Namun, di balik kemudahan berkomunikasi melalui dunia maya melalui pesan singkat yang dilakukan oleh siswa kepada guru maupun mahasiswa kepada dosen harus tetap mengikuti sikap kesantuntan dalam berbahasa.

Hasil pengamatan yang dilakukan peneliti selama kegiatan pembelajaran daring melalui aplikasi zoom, google classroom, dan whatsapp masih banyak ditemukan penggunaan bahasa yang mengabaikan sikap kesantuntan, baik berkomunikasi kepada dosen maupun pada saat kegiatan berdiskusi. Hal tersebut cukup banyak ditemui selama pembelajaran daring. Salah satu contoh ketika mahasiswa melakukan kegiatan diskusi melalui google classroom “... penjelasan saudara tidak bisa dipahami ..." Dari contoh tersebut dapat memberikan gambaran bahwa pemilihan kata maupun penggunaan gaya bahasa sangat penting walaupun kegiatan pembelajaran dilakukan secara daring.

Penelitian yang berkaitan dengan kesantunan berbahasa sudah banyak diteliti dan dipublikasikan oleh peneliti sebelumnya. Sebagaimana penelitian yang dilakukan Fatmawati, Boeriswati, dan Zuriyati (2020) berjudul The Realization of Students' Polite Rejection Speeches. Penelitian ini menggunakan metode deskriptif kualitatif dengan pendekatan fenomenologi. Hasil penelitian mengungkapkan bahwa penolakan kesopanan lebih dominan digunakan yang disertai alasan, seperti, menolak tawaran, ajakan, perintah maupun himbauan yang dianggap lebih tepat untuk diungkapkan dan tidak merugikan lawan tutur. Hal ini tidak jauh berbeda dengan temuan penelitian Ningsih, Boeriswati, dan Muliastuti (2020) yang berjudul Language Politennes of Students and Teachers: An Etnographic Study. Penelitian ini menggunakan metode deskriptif kualitatif dengan pendekatan etnografi. Temuan penelitian mengungkapkan bahwa tunturan antara guru dan siswa sudah dapat dikategorikan sopan. Hal tersebut tampak bahwa dari 101 ujaran yang ditemukan, hanya 38 ujaran yang dikategorikan tidak sopan atau melanggar enam kaidah kesantunan sesuai dengan pendapat yang dikemukakan Leech.

Hasil penelitian selanjutnya dilakukan oleh Wahidah dan Wijaya (2017) dengan judul Analisis Kesantunan Berbahasa Menurut Leech pada Tuturan Berbahasa Arab Guru Pondok Pesantren Ibnul Qoyyim Putra Yogyakarta (Kajian Pragmatik). Hasil temuan berdasarkan teori Leech mengungkapkan bahwa terdapat 17 maksim kebijaksanaan, 4 maksim kedermawanan, 14 maksim penghargaan, 25 maksim kemufakatan, dan 4 maksim kesimpatasin. Selain itu, juga ditemukan beberapa maksim pelanggaran dalam proses pembelajaran. Temuan yang sama juga dikemukakan Febriasari dan Wijayanti (2018) dalam suatu penelitian berjudul Kesantunan Berbahasa dalam Proses Pembelajaran di Sekolah Dasar. Hasil temuan mengungkapkan bahwa beberapa tuturan siswa telah mematuhi maksim kebijaksanaan, kedermawanan, penghargaan, kesederhanaan, permufakatan, dan kesimpatisan. Namun, beberapa siswa juga melanggar maksim tersebut.

Berdasarkan permasalahan yang telah diuraikan tampak bahwa penelitian ini cukup penting untuk dilakukan. Hal ini didasari bahwa santun dalam berbahasa tidak hanya dilakukan dalam pembelajaran tatap muka, tetapi kesantunan juga sangat penting walaupun pembelajaran dilakukan secara daring agar peserta tutur bisa saling 
menerima dan memahami maksud sebuah tuturan. Selain itu, dari hasil kajian penelitian relevan tampak bahwa peneliti sebelumnya belum ada yang melakukan penelitian terkait dengan kesantunan berbahasa dalam pembelajaran daring, sehingga penelitian ini menarik untuk diulas secara mendalam melalui sebuah penelitian.

\section{Metode Penelitian}

Penelitian ini menggunakan metode deskriptif kualitatif. Metode kualitatif ialah bentuk penelitian yang dialami oleh subjek penelitian, seperti perilaku, persepsi, motivasi, maupun tindakan secara deskriptif dalam bentuk bahasa dengan memanfaatkan metode ilmiah (Moleong, 2007).

Sumber data dalam penelitian ini ialah mahasiswa Universitas Cokroaminoto Palopo. Data dalam penelitian ini berupa tuturan mahasiswa sesuai dengan teori kesantunan yang dikemukakan Leech (1993). Teori kesantunan tesebut mencakup maksim kebijaksanaan, kedermawanan, penghargaan, kesederhanaan, permufakatan, dan kesimpatisan.

Pengumpulan data yang dilakukan dalam penelitian ini melalui observasi, simak, dan pencatatan. Adapun teknik analisis data yang dilakukan dalam penelitian ini, terdiri atas beberapa tahap. Pertama, data yang berupa tuturan lisan pada pembelajaran daring melalui zoom dikumpulkan dan ditranskripkan ke dalam bahasa tulis. Kedua, melakukan proses reduksi data dengan mengidentifikasi dan mengklasifikasikan tuturan-tuturan yang termasuk dalam tuturan kesantunan. Ketiga, menyajikan data. Keempat, menarik kesimpulan dari hasil interpretasi setelah data disajikan.

\section{Hasil dan Pembahasan}

Berdasarkan hasil analisis terhadap beberapa tuturan mahasiswa selama pembelajaran daring berlangsung ditemukan beberapa tuturan yang mematuhi dan melanggar prinsip kesantunan berbahasa. Pematuhan dan pelanggaran prinsip kesantunan berbahasa dalam pembalajaran daring meliputi: (1) maksim kebijaksanaan; (2) maksim kedermawanan, (3) maksim penghargaan; (4) maksim kemufakatan; dan (5) maksim kesimpatisan. Berikut data temuan tuturan pematuhan dan pelanggaran prinsip kesantunan berbahasa dalam kegiatan pembelajaran daring.

\section{Maksim Kebijaksanaan (Pematuhan)}

\section{Data 1}

Penutur: Assalamuaalaikum Pak, maaf sebelumnya, bisa kah saya kirim tugasku lewat WA saja Pak karena tidak bagus jaringanku kalau kirim lewat classroom?

Lawan tutur: Waalaikumsalam, iya bisa dikirm lewat WA saja.

\section{Data 2}

Penutur: Assalamualaikum, maaf Pak, bisa ga saya tulis tangan saja itu tugasku di kertas baru saya foto?

Lawan tutur: Waalaikumsalam wr. wb. Iya silakan ditulis kemudian diunggah ke google classroom, melalui komentar pribadi.

Konteks tuturan yang terdapat pada data di atas termasuk dalam maksim kebijaksanaan dari aspek pematuhan. Sebagaimana tuturan yang tampak pada data pertama terjadi komunikasi antara mahasiswa dengan dosen. Mahasiswa tersebut ingin mengirimkan tugas melalui whatsapp karena terkendala jaringan sehingga tidak mampu untuk mengirimkan melalui google classroom dan kemudian direspons oleh dosen dengan mengisinkan mahasiswa tersebut untuk mengirimkan tugasnya melalui classroom. 
Selanjutnya data kedua juga memberikan gambaran proses komunikasi antara mahasiswa dan dosen melalui pesan whatsapp. Mahasiswa tersebut meminta kebijakan dosen bahwa tugasnya bisa dikerjakan dengan cara menulis kemudian menggunggah ke akun pribadi google classroom. Secara langsung permintaan tersebut direspons dengan bijak oleh dosen dengan mengisinkan mahasiswa tersebut untuk mengerjakan tugas sesuai kemampuannya.

Dapat disimpulkan bahwa kedua data tersebut merupakan tuturan yang bersifat santun dalam berbahasa. Kesantunan tersebut tampak dari maksim kebijaksanaan yang diberikan oleh dosen kepada mahasiswa untuk mengerjakan tugas sesuai kemampuannya. Hal ini juga tidak jauh berbeda dengan pendapat Wahidah dan Wijaya (2017) bahwa seseorang yang berpegang pada maksim kebijaksanaan, ia dapat menghindari perbuatan dengki, iri hati, dan sikap kurang santun terhadap mitra tutur.

\section{Maksim Kedermawanan (Pematuhan)}

Penutur: Ok, saya akan membantu memberikan jawaban dari kelompok 3. Hubungan bahasa dan budaya ialah....

Bagaimana dengan jawaban saya?

Lawan tutur: Baik, jawabannya sudah saya terima. Terima kasih

Konteks tuturan yang terdapat pada data di atas termasuk dalam maksim kedermawanan dari aspek pematuhan. Sebagaimana tuturan yang tampak pada data tersebut terjadi komunikasi antara mahasiswa dalam kegiatan diskusi melalui google classroom. Tuturan tersebut tampak dari salah seorang peserta diskusi yang ingin membantu kelompok 3 untuk menjawab pertanyaan dari peserta diskusi yang lain karena kelompok 3 tidak mampu menyampaikan jawaban secara detail. Dapat disimpulkan bahwa tuturan tersebut bersifat santun dalam berbahasa. Kesantunan tersebut tampak dari maksim kedermawanan karena salah seorang mahasiswa memiliki rasa empati untuk membantu rekannya yang terlihat kesulitan dalam memberikan jawaban.

\section{Maksim Penghargaan}

Data temuan penelitian pada maksim penghargaan ditemukan dua bentuk yaitu pematuhan dan pelanggaran.

\section{Pematuhan}

Penutur: Assalamualaikum wr, wb. saya ingin bertanya bisakah anda menjelaskan dari kedua masalah yang menjadi fokus perhatian antropologi?

Lawan tutur: Yang pertama kepribadian bangsa yang dimaksud adalah .... Itulah jawaban dari kelompok kami, bagiamana dengan saudara Yuli?

Penutur: Baik, terima kasih kepada kelompok penyaji, jawabannya sudah sangat baik, karena sudah dipaparkan secara rinci.

Konteks tuturan yang terdapat pada data di atas termasuk dalam maksim penghargaan dari aspek pematuhan. Sebagaimana tuturan yang tampak pada data tersebut terjadi komunikasi antara mahasiswa dalam kegiatan diskusi melalui google classroom. Tuturan tersebut tampak dari peserta diskusi yang mengajukan pertanyaaan kepada kelompok penyaji terkait dengan materi yang didiskusikan dan secara langsung direspons oleh penyaji dengan memberikan jawaban. Selanjutnya, peserta diskusi tersebut menerima jawaban karena sudah diuraikan dengan baik oleh kelompok penyaji. 


\section{Pelanggaran}

Penutur: Baik, di sini saya tidak ingin bertanya ke kelompok 3, tapi maaf saya ingin mengoreksi PPT kelompok 3. Pada slide ke 3 terdapat beberapa huruf " $L$ " yang di bold, apakah itu unsur kesengajaan atau tidak karena ada huruf " $L$ " yang lain tidak di bold.

Lawan Tutur: Baik... teruntuk saudari Lisnawati....

Huruf ' $L$ ' yang di bold itu dikarenakan kesalahan jari tangan saya sehingga Huruf ' $L$ ' tersebut saya Blog sehingga bisa jadi seperti itu. (KELIRU,TIDAK SENGAJA, DAN KURANG HATI-HATI).

Konteks tuturan yang terdapat pada data di atas termasuk dalam maksim penghargaan dari aspek pelanggaran. Sebagaimana tuturan yang tampak pada data tersebut terjadi komunikasi antara mahasiswa dalam kegiatan diskusi melalui google classroom. Tuturan tersebut tampak dari peserta diskusi yang mengajukan tanggapan dari slide presentasi yang dibawakan oleh kelompok 3 karena ada beberapa slide yang seakan-akan diberikan penekanan dari huruf L. Namun kelompok penyaji memberikan respons yang kurang santun dalam berbahasa. Sebaiknya kelompok penyaji menyampaikan permohonan maaf dan menerima saran untuk melakukan perbaikan atas kesalahan yang dilakukan. Hal tersebut sesuai dengan pendapat yang dikemukakan Mislikhah (2020) bahwa salah satu faktor munculnya bahasa tidak santun ialah dipengaruhi penutur yang protektif terhadap pendapatnya agar tuturan mitra tutur tidak dipercaya oleh pihak lain.

\section{Maksim Kemufakatan}

Data temuan penelitian pada maksim kemufakatan diperoleh dua bentuk yaitu pematuhan dan pelanggaran.

\section{Pematuhan}

Penutur: Baik, sesuai dengan kontrak perkuliahan, khususunya dari aspek penilaian, apakah semua sudah disepakati?

Lawan tutur: Mohon maaf Pak, saya ingin memberikan sedikit tanggapan, apakah persentase kehadiran, apakah bisa hanya 20\% saja?

Penutur: Iya bisa, yang penting semua temannya sepakat.

Lawan tutur: Semua mahasiswa serentak menjawab, sepakat.

Konteks tuturan yang terdapat pada data di atas termasuk dalam maksim kemufakatan dari aspek pematuhan. Sebagaimana tuturan yang tampak pada data tersebut terjadi komunikasi antara dosen dan mahasiswa dalam kegiatan diskusi melalui aplikasi zoom. Tuturan tersebut tampak dari dosen yang meminta tanggapan mahasiswa terkait dengan penyampaian kontrak perkuliahan yang disampaikan. Namun salah seorang mahasiswa memberikan respons dengan menggunakan bahasa yang santun untuk menurunkan persentase kehadiran. Selanjutnya, dosen kembali mempersilakan mahasiswa untuk menanggapi dan semuanya menyatakan setuju. Dari konteks tersebut tampak bahwa mahasiswa memberikan tanggapan secara santun. Kesantunan tersebut tampak dari maksim kemufakatan antara dosen dan mahasiswa dalam penyampaian kontrak perkuliahan dari aspek penilaian. 


\section{Pelanggaran}

Data 1

Penutur: Bagaimana dengan jawaban yang diberikan oleh kelompok kami?

Lawan tutur: Saya masih belum bisa menerima jawabannya karena menurut saya itu kurang tepat, harusnya dijabarkan scara detail.

Konteks tuturan yang terdapat pada data di atas termasuk dalam maksim kemufakatan dari aspek pelanggaran. Sebagaimana tuturan yang tampak pada data tersebut terjadi komunikasi antara mahasiswa dalam kegiatan diskusi melalui google classroom. Tuturan tersebut tampak dari peserta diskusi yang tidak bisa menerima jawaban dari kelompok pemateri. Dari konteks tersebut tampak bahwa salah seorang peserta diskusi memberikan tanggapan kurang santun. Sebaiknya, peserta diskusi tidak secara langsung menyalahkan jawaban dari pemateri.

Data 2

Penutur: Assalamualaikum Pak, bagaimana perkuliahan ini apakah akan berjalan

Lawan tutur: Waalaikumsalam, tadi saya sampaikan ke temannya yang presentasi, pekan depan saja karena ada kegiatan.

Penutur: Oiya

Konteks tuturan yang terdapat pada data kedua termasuk dalam maksim kemufakatan dari aspek pelanggaran. Sebagaimana tuturan yang tampak pada data tersebut terjadi komunikasi antara mahasiswa dan dosen melalui pesan whatsapp. Dari konteks tersebut tampak bahwa mahasiswa memberikan tanggapan secara kurang santun. Sebaiknya, mahasiswa memberikan tanggapan dengan menjawab, "baik Pak, terima kasih atas informasinya".

Dapat disimpulkan bahwa kedua data tersebut merupakan tuturan yang bersifat kurang santun dalam berbahasa. Kesantunan tersebut tampak dari pelanggaran maksim kemufakatan antara pemateri dengan peserta diskusi dan antara mahasiswa terhadap dosen. Hal ini juga tidak jauh berbeda dengan temuan Cahyaningrum, Andayani, \& Setiawan (2018) tentang maksim kemufakatan antara penutur dalam proses komunikasi. Hal tersebut tampak ketika siswa melakukan kegiatan diskusi yang saling menyepakati jawaban antara pemateri dan peserta diskusi.

\section{Maksim Kesimpatisan (Pematuhan)}

Penutur: Assalamualaikum Pak, mohon maaf sebelumnya, kemarin saya belum bisa mengikuti perkuliahan di classroom karena kurang sehat. Maaf Pak, penyamapaiannya telat.

Lawan tutur: Waalaikumsalam wr.wb. Baiik, tidak apa-apa, semoga lekas sembuh ya.

\section{Penutur: Terima kasih Pak.}

Konteks tuturan yang terdapat pada data di atas termasuk dalam maksim kesimpatisan dari aspek pematuhan. Sebagaimana tuturan yang tampak pada data tersebut terjadi komunikasi antara mahasiswa dan dosen melalui pesan Whatsapp. Tuturan tersebut tampak dari mahasiswa yang menyampaikan permohonan maaf tidak mengikuti perkuliahan online karena sakit. Dari konteks tersebut tampak bahwa mahasiswa memberikan tanggapan secara santun dan direspons oleh dosen dengan rasa simpati. Hal ini sesuai dengan pendapat yang dikemukakan Brown (2015) bahwa kesantunan dalam berbahasa ialah memperhitungkan perasaan orang lain tentang cara mereka untuk diperlakukan secara bijak dan bisa saling memahami. 


\section{Simpulan}

Berdasarkan hasil temuan pada penelitian ini dapat disimpulkan bahwa mahasiswa Universitas Cokroaminoto Palopo selama kegiatan pembelajaran online dapat dikatakan santun dalam berbahasa. Hal tersebut tampak dari hasil analisis menggunakan teori Leech ditemukan 5 maksim yang termasuk pada tuturan pematuhan, yang mencakup maksim kebijaksanaan, kedermawanan, penghargaan, kemufakatan, dan kesimpatisan. Hanya maksim kesederhanaan yang tidak ditemukan dalam penelitian ini. Selain itu, dari temuan tersebut hanya maksim penghargaan dan kemufakatan yang terjadi pelanggaran dalam berbahasa.

\section{Daftar Pustaka}

Adriana, I. (2014). Analisis Bahasa SMS Mahasiswa STAIN Pamekasan terhadap Dosen menurut Prinsip Kesantunan Leech. NUANSA: Jurnal Penelitian Ilmu Sosial dan Keagamaan Islam, 11(1), 53-76.

Alviah, I. (2014). Kesantunan berbahasa dalam tuturan novel Para Priyayi karya Umar Kayam. Seloka: Jurnal Pendidikan Bahasa dan Sastra Indonesia, 3(2).

Brown, P. (2015). Politeness and language. In The International Encyclopedia of the Social and Behavioural Sciences (IESBS), (2nd ed.) (pp. 326-330). Elsevier.

Cahyaningrum, F., Andayani, A., \& Setiawan, B. (2018). Kesantunan Berbahasa Siswa dalam Berdiskusi. Madah, 9(1), 45-54.

Darwis, M. (2018). Politeness Language Analysis in Teenagers Reviewed from Sociolinguistics. Budapest International Research and Critics in Linguistics and Education (BirLE) Journal, 1(1), 15-22.

Fatmawati, Boeriswati, E., \& Zuriyati. (2020). The Realization of Students' Polite Rejection Speeches. Journal GEEJ: Pendidikan Bahasa Inggris, 7(1), 134-147.

Febriasari, D., \& Wijayanti, W. (2018). Kesantunan Berbahasa dalam Proses Pembelajaran di Sekolah Dasar. Jurnal Kredo, 2(1).

Leech, G. N. (1993). Prinsip-prinsip Pragmatik. Jakarta: UI Press.

Mislikhah, S. (2020). Kesantunan berbahasa. Ar-Raniry, International Journal of Islamic Studies, 1(2), 285-296.

Moleong, L. J. (2007). Metodologi Penelitian Kualitatif. Bandung: Remaja Rosda Karya.

Ningsih, Boeriswati, E, \& Muliastuti, L. (2020). Language Politennes of Students and Teachers: An Etnographic Study. Journal GEEJ: Pendidikan Bahasa Inggris, 7(1), 134-147.

Wahidah, Y. L., \& Wijaya, H. (2017). Analisis Kesantunan Berbahasa Menurut Leech pada Tuturan Berbahasa Arab Guru Pondok Pesantren Ibnul Qoyyim Putra Yogyakarta (Kajian Pragmatik). Jurnal Al Bayan, 9(1). 